\title{
PRO-ENVIRONMENTAL ARCHITECTURE AIMED AT CHILDREN - FUTURE CHALLENGES, EDUCATIONAL MESSAGE
}

\author{
Agnieszka Starzyk ${ }^{凶}$
}

Faculty of Architecture, University of Ecology and Management in Warsaw

\begin{abstract}
The scientific goal was to examine the impact of pro-environmental challenges of the future on shaping architecture aimed at children, as well as to study an educational factor within the scope of pro-environmental message implemented by means of architecture. In order to define and solve the scientific problem of the following study, the necessary research methods were applied. These included analysis and criticism of literature, observation with no intervention, case study and the intuitive method, based on the author's personal experience. When analysing architecture in the context of future challenges, a selection was made so as to indicate issues that could exert the greatest impact on the development of facilities aimed at children. The challenges defined are as follows: greater activity of disabled people, increasing health and psychological problems among children, increasing environmental and climate changes. The architecture of the future should rise to the already defined challenges, but also be able to face the emerging new ones.
\end{abstract}

Key words: architecture aimed at children, environment, future, education

\section{INTRODUCTION}

From the perspective of contemporary times, it is difficult to clearly determine what the architecture of the future will be like, what social and environmental conditions will have an impact on it, either directly or indirectly. The scientific goal of the present study was to examine the impact of future environmental and social challenges on shaping architecture aimed at children. The educational message is of great importance here, namely the pro-environmental message implemented by means of architecture. A message that articulates how important it is to strive at transformation of a place/space from the selfish (selfish ecosystem) into a responsible ecosystem, i.e. one whose functioning imposes a burden as low as possible upon other ecosystems that function on Earth (Kubec, 2017).
The educational message of pro-environmental architecture is directly related to the child's attitude/behaviour, and its effects may vary and depend on personal factors. The impact of human attitude on the effectiveness of their activities has provided subject for interdisciplinary research for many years now. A significant research was conducted by E. Scott Geller, a behavioural psychologist and the author of the 'Actively Caring' concept. The research indicated factors that shape behaviours aimed at environmental protection, the mutual relationship between behaviour-based psychology (BBP) and person-based psychology (PBP) - one defines circumstances and/or expectations that motivate people to actively care for the environment, while the other indicates tools for changing behaviour and attitudes. Geller indicated personal factors that exert impact on the development of an 
active pro-environmental attitude. These include: self-esteem, a sense of belonging, a sense of self-efficacy, self-control, optimism (Geller, 1995).

Buildings directly account for around $1 / 3$ of the total global energy consumption and for around $1 / 5$ of the energy-related greenhouse gas emissions. For the sake of further observations, it is important to note that in addition to technological solutions, behavioural patterns and lifestyle in general have a significant impact on energy consumption in buildings (IPCC, 2014; Wróbel, 2019).

\section{MATERIAL AND METHODS}

In order to analyse, evaluate and synthesize the research material, the following methods were applied: analysis and criticism of source literature, observation with no intervention, case study, as well as the intuitive method, based on the author's personal experience.

The research was conducted in the following stages: (1) analysis of the diagnosed research problem, criticism of the issue in the light of previous research; (2) case study - analysis of projects and their implementation; (3) analysis of materials, classification of research material; (4) study and synthesis of materials collected during research; (5) study of research results.

Another significant factors for undertaking the research topic included the author's previous scientific research published in scientific publications and presented at conferences - confrontation of results with other research conducted by the author, as well as the author's professional practice in the field of architectural design, including objects aimed at children. The profession of architect belongs under a few professions in which, prior to each new design task, one should familiarize themselves with additional knowledge in order to be able to responsibly and properly fulfil the task they were entrusted with.

\section{RESULTS}

While analysing architecture in the context of the future challenges, both positive and negative ones, a selection was made with the aim of indicating issues that are likely to exert the greatest impact on shaping objects aimed at children, i.e. greater activity of disabled people (a positive phenomenon, but one that requires deepening the knowledge and greater empathy on the part of designers), increasing health problems (including obesity, cardiovascular disease, diabetes, allergies), increasing amounts of mental disorders among children, but also increasing environmental and climate changes (Fig. 1).

The increasing amounts of mental disorders pose a new civilisation threat, most of which originate in childhood. Previous studies of spaces aimed at children were focused on inducing specific emotions/

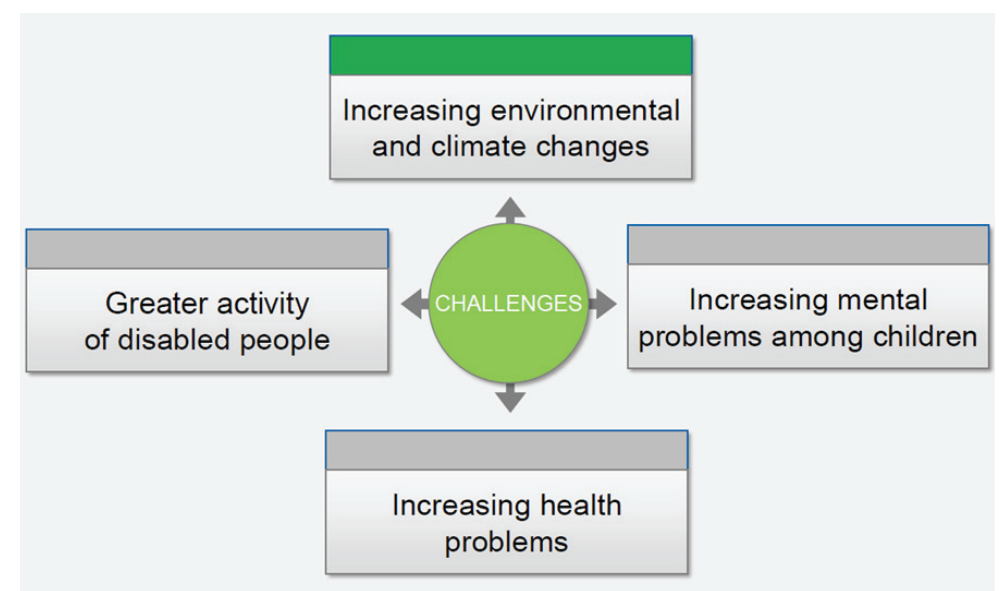

Fig. 1. Architecture aimed at children - future challenges (own elaboration) 
/behaviours, as if the child that enters this space were emotionally neutral. Modern children tend to be over-stimulated in many areas, both mentally and physically. The research has finally defined the problem of transferring the weight of stimulation to: minimizing the stress children experience, and not generating new sources of stress. This requires a new approach to space aimed at children, as well as it needs in-depth interdisciplinary research, including research with large participation by psychologists and psychiatrists (Starzyk, 2019).

In the present study, the author's predominant focus was on pro-environmental challenges. Nowadays, a number of trends of architecture defined in such a way can be distinguished. In the context of architecture aimed at children, it seems that practical applications comprise: ecological architecture and sustainable development architecture. It should, however, be emphasized at this point that pro-environmental trends in general interpermeate, whereas their definitions vary depending on the specifics of the place and object, as well as the author's opinions and, thus, are constantly subject to modification (Starzyk, 2019).

Frank Lloyd Wright was the precursor of ecological architecture. His organic implementations were characterised by being inscribed in the natural context of the place and by giving emphasis to the surrounding environment inside the building. The works of Wright may be seen as an earnest of architecture based on the use of natural materials and plant biodiversity in conjunction with the surrounding landscape (Banasik-Petri, 2018). During a speech at the Institute of British Architects in London in 1939, F. L. Wright presented his definition of modern, namely, organic architecture: "Organic architecture favours a free, unforced, natural position. Its supernatural symmetry involves the quality of being picturesque and a rhythm combined with the environment that corresponds to the rhythm of the charms of a free life adapted to nature. He believed that 'the nature of the area where it is implemented provides the basis for architecture' [own translation]" (Łysiak, 1999).

Currently, numerous pro-environmental trends can be distinguished. It seems that the three most wide-spread trends include: ecological architecture, bioclimatic architecture and sustainable development architecture. Ecological architecture is characterized by a form dependent on the requirements of energy-saving design and is implemented with regard to the existing environment. Construction, material, technological and functional solutions are applied, with which to ensure the maximum possible usage comfort with minimum environmental costs, as well as in order to optimize the advantage from daylight and natural ventilation. Formal solutions are characterized by incorporating the object into the surrounding landscape, by opening the internal space to the surroundings and by maximizing the user's contact with nature. The use of renewable energy sources (RES) is crucial when it comes to ecological construction. Educational message is of great importance, namely pro-environmental message implemented by means of architecture. Adapting the building to local climatic and biological conditions, while showing full respect for the socio-cultural context should be seen as the basic feature of bioclimatic architecture. In case of sustainable development architecture, the following three priority areas are distinguished: ecology, economy and society. The common overarching goal of these three trends may be sought in implementation of healthy and comfortable places/facilities for users, while respecting the existing natural environment.

According to Widera (2018), however, in case of pro-environmental architecture, "biological integrity, consisting in the full integration of all elements of a building [...] with: users' (living inhabitants of the ecosystem) needs, the direct surroundings perceived as part of the natural and cultural environment, the nature and its phenomena (sun, wind, watercourses, geological substratum, biocoenosis)" has not been achieved as yet. Hence the idea of biological architecture, wherein "the basic difference between ecological and bioclimatic research streams and biological architecture consists in the transition from designing such built environment that does not pose a threat to the security of the natural environment and uses its resources in a rational way so as to meet the requirements of user comfort and in a transition from designing built environment adapted to local cultural and bioclimatic conditions, to create an integrated biological environment shared by humans and other living organisms that are part of the ecosystem [own translation]". 
Nowadays, the above issues are being emphasised and, as a consequence, solutions referred to as wildlife are gradually becoming a trend in landscape architecture design. Scientifically speaking, wildlife is all animate nature, but commonly "wildlife, a part of the nature of a given area, is understood as mushrooms, plants and animals that permanently exist (or are able to exist) without deliberate human help [own translation]" (Luniak, 2019). In addition to wildlife, the ecosystem encompasses also cultivated life or cultured life, i.e. living organisms introduced by mankind, for which human lasting help provides the condition of existence. Cultivated life, however, does not add to the natural biodiversity of the area (Luniak, 2019). Wildlife can be found in all ecosystems. Unconstrained vegetation characteristic of wasteland is associated with biodiversity by recipients, and is, therefore, linked with high values of nature, biophilia and environmental security. According to Gawryszewska and Biernacka (2019): "In the eyes of inhabitants, the aesthetics of wasteland has become the aesthetics of nature, authentic and rationalized as appropriate [own translation]".

Ecological security and adaptation measures intended at areas sensitive to climate change are also important in the context of shaping architecture. A sense of security (subjective feeling) is as important as objective security. Especially in the case of architecture aimed at children, displaying or overly escalating space protection elements can evoke a sense of danger or even panic. On the contrary, unsecured space can lead to a false sense of security. No typical universal solutions can be provided, each place requires a threat and security analysis, as well as creativity in the design process. It is essential to adopt a comprehensive and holistic approach, to design security measures well integrated into the context of a given place.

Threats common these days include floods, urban heat islands, water deficiency, heavy rains and flooding. These problems require interdisciplinary activities, such as: assessment of the city sensitivity and planning comprehensive adaptation actions, effective spatial planning with account for climate risks, effective management of rainwater (including rainwater use), expansion of green and water areas, revitalization of nature ${ }^{1}$.

The level of ecological awareness in society is on the increase, but it is still not satisfactory, whereas education should be commenced from an early age by observation of good practices, both in the context of architecture and everyday activities. Kindergartens by HIBINOSEKKEI + Youji no Shiro $^{2}$ implemented in Japan can be given as a good example of this approach. By conducting continuous pre-design research, the designers of those kindergartens respond with formal, aesthetic and functional-spatial solutions to the changing social situation and to pro-environmental challenges. Kindergartens in which the child serves as both the measure and the scale are designed. Creative child-friendly spaces encourage physical activity and teach good habits. The concept of 'feel nature, increase sensitivity' is implemented here through a variety of solutions, including the readability of pro-environmental technologies (Fig. 2a, 2b) and the transparency of the activities taken by all users in order to teach good habits related to issues such as saving water or energy, or healthy eating habits (Fig. 2c).

The research conducted by Parisa Izadpanahi, Hisham Elkadi and Richard Tucker in Australia in primary schools, grades 4,5 and 6 , i.e. among children from 9 to 12 years of age, is important in the context of the topic discussed in the present paper. The study was aimed at determining how pro-environmental solutions applied in the school building architecture affect the attitudes of students and whether such a correlation occurs at all. The New Ecological Paradigm (NEP) scale, adjusted to the

\footnotetext{
1 'National Urban Policy' conference held on 13 June 2013, author's notes from the speech given by Szymon Tumielewicz, the Deputy Director of the Department of Sustainable Development in the Polish Ministry of the Environment.

${ }^{2}$ Youji no Shiro is one of the sections of the HIBINOSEKKEI studio based in Kanagawa, Japan, founded in 1972 by Taku Hibino. The section called Youji no Shiro, which in Japanese means 'castle for children', was created in 1991 and specializes in designing spaces for children, mainly kindergartens.
} 
a

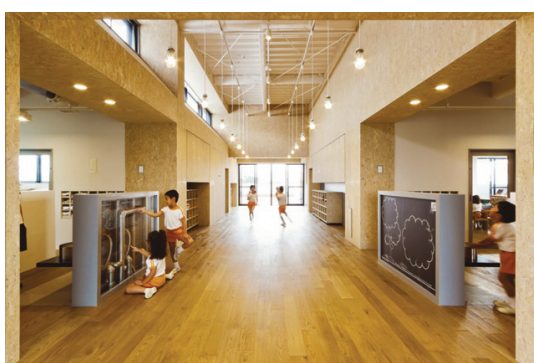

b

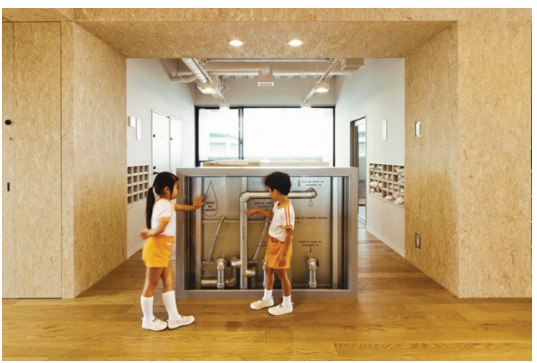

c

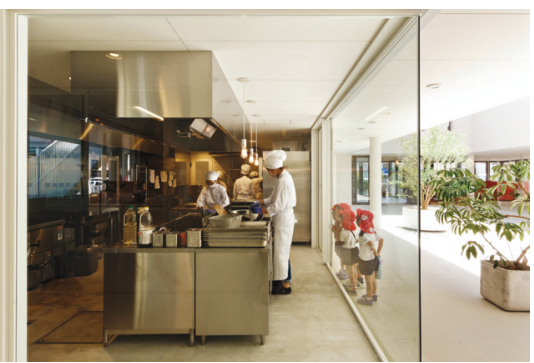

Fig. 2. Educational message of architecture aimed at children, kindergarten projects by HIBINOSEKKEI + Youji no Shiro studio: a, b - in Nara (Japan), implementation 2016; c - in Kumamoto (Japan), implementation 2015 (C) Ryuji Inoue / Studio Bauhaus)

Australian background of studying children, teachers and caregivers/parents was applied for measurement. The research results proved a correlation between pro-environmental solutions applied in educational facilities and the approach of users thereof (children, teachers, caregivers/parents) to ecology. The results obtained in the research lead to conclusions that indicate solutions for shaping pro-environmental attitudes. These are as follows: solar panels, the use of recycled water, natural lighting, outdoor educational spaces, food production for own needs (Izadpanahi, Elkadi \& Tucker, 2015).
Architecture aimed at children is of particular importance in preparing the youngest generation to building a better future for our planet. The building, as a model of good practice, serves as a very important element in the educational process. The list of solutions is wide and still open. As a result of the analysis, four examples of solutions were selected that are applicable at only small additional financial expenses, namely: exposed building elements, exposed renewable energy sources (RES), exposed rainwater management technology, exposed air quality indicators (Fig. 3).

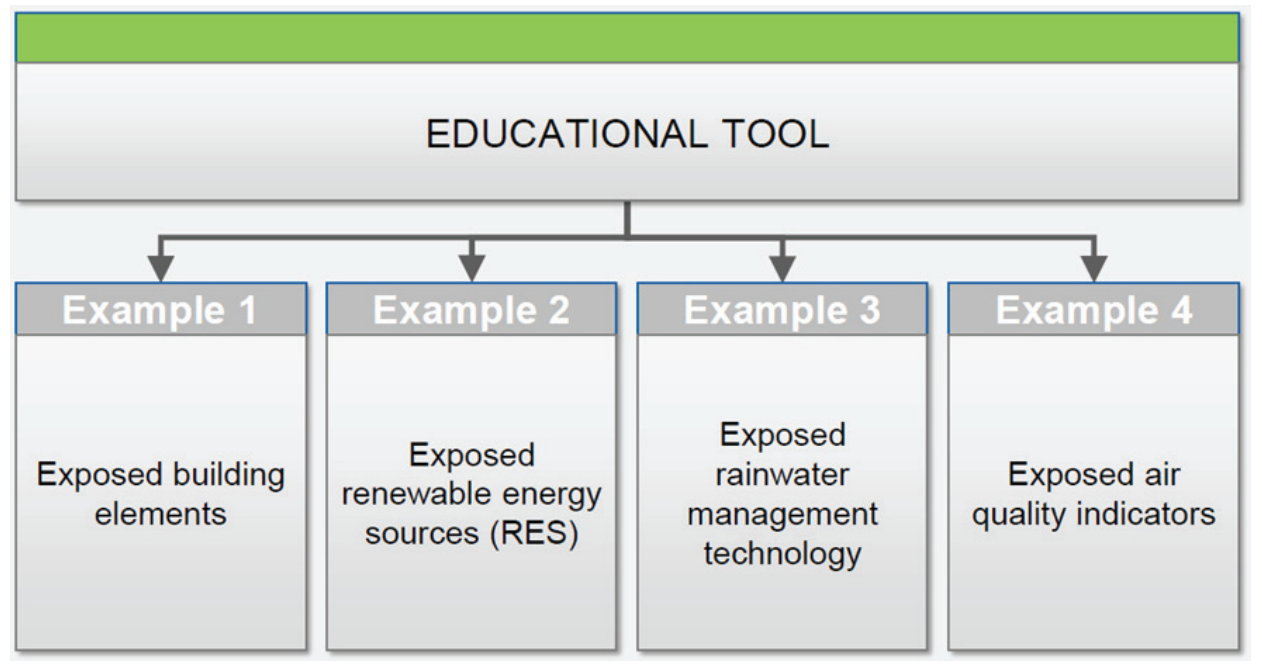

Fig. 3. Architecture aimed at children - educational message (own elaboration) 


\section{CONCLUSIONS}

The architecture of the future should provide answers to already defined challenges, but also react to emerging new ones. In the process of shaping architecture addressed to children, the role of architects is to awaken the ecological awareness of the youngest, to convey educational message mainly regarding issues, such as biodiversity and nature protection, air and water quality, and energy and its relationship with the environment (RES).

The effectiveness of actions taken in order to convey the pro-environmental educational message depends on the connection with competences indicated as prospective priorities in the educational process:

- cooperation - cooperating and response to the actions of others;

- emotional intelligence - understanding people's emotions and needs and responding to them;

- critical thinking - perceiving many points of view and analysing the strengths and weaknesses of various ideas;

- cognitive flexibility - multidirectional thinking and implementation of multifaceted challenges;

- problem solving - dealing with complex problems in real situations;

- technical and digital competences - using technology to solve problems and to search for information.

It is only by means of comprehensive thinking about future challenges in the context of educational message, with account of both hard competences related to knowledge, as well as the above-mentioned soft competences that the assumed effects can be achieved. Attention should also be paid to the already noticeable change in behaviour in the group of youngest children, as the youngest tend to be more mobile than previous generations. It may be concluded that the society of the future will also be more mobile, which will require a new approach to space. Since architecture should respond in advance to future challenges, pre-design research, which, according to the author, should be the standard, ought to account for all of the above conclusions.

\section{REFERENCES}

Banasik-Petri, K. (2018). Architektura proekologiczna. Rozwiąania artystyczne $w$ zielonej architekturze. Kraków: Oficyna Wydawnicza AFM.

Gawryszewska, B. J. \& Biernacka, J. (2019). Zieleń w Warszawskim Standardzie Mieszkaniowym. Acta Sci. Pol. Architectura, 18 (3), 3-14. DOI: 10.22630/ ASPA.2019.18.3

Geller, E. S. (1995). Actively Caring for the Environment: An Integration of Behaviorism and Humanism. Environment and Behavior, 27 (2), 184-195. DOI: 10.1177/0013916595272004

Intergovernmental Panel on Climate Change [IPCC] (2014). Climate Change 2014: Mitigation of Climate Change. In Working Group III to the Fifth Assessment Report of the Intergovernmental Panel on Climate Change. Cambridge: Cambridge University Press. Retrieved from https://www.ipcc.ch/site/assets/uploads/2018/02/ ipcc_wg3_ar5_frontmatter.pdf [accessed 13.10.2019].

Izadpanahi, P., Elkadi, H. \& Tucker, R. (2015). Greenhouse affect: the relationship between the sustainable design of schools and children's environmental attitudes. Journal Environmental Education Research, 23 (7), 901-918. DOI: 10.1080/13504622.2015.1072137

Kubec, J. (2017). O architekturze na styku obszaru zurbanizowanego i krajobrazu otwartego. Gliwice: Wydawnictwo Politechniki Śląskiej.

Luniak, M. (2019). Dzikie życie w parkach miejskich - jak mu sprzyjać. Warszawa: Zarząd Zieleni m.st. Warszawy.

Łysiak, W. (1999). Frank Lloyd Wright. Warszawa-Chicago: Ex Libris.

Starzyk, A. (2019). Wspótczesna architektura przedszkolna. Studium obiektów zrealizowanych $w$ Warszawie w latach 2000-2018. Warszawa: Oficyna Wydawnicza Politechniki Warszawskiej.

Widera, B. (2018). Proces ksztaltowania relacji z natura w architekturze współczesnej. Wrocław: Oficyna Wydawnicza Politechniki Wrocławskiej.

Wróbel, P. (2019). Transformations in Relations between Architecture and Nature under the Influence of Climate Change. Space \& Form, 39, 143-156. DOI: 10.21005/ pif.2019.39.B-08 


\section{PROŚRODOWISKOWA ARCHITEKTURA PRZEZNACZONA DLA DZIECI - WYZWANIA PRZYSZŁOŚCI, PRZEKAZ EDUKACYJNY}

\section{STRESZCZENIE}

Celem naukowym było zbadanie wpływu prośrodowiskowych wyzwań przyszłości na kształtowanie architektury przeznaczonej dla dzieci, a także czynnika edukacyjnego w zakresie przesłania prośrodowiskowego realizowanego poprzez architekturę. Zastosowano metody badań niezbędne do zdefiniowania i rozwiązania problemu naukowego: analizy i krytyki piśmiennictwa, obserwacji bez interwencji, studium przypadku, metodę intuicyjną wykorzystującą osobiste doświadczenia autorki. Analizując architekturę w kontekście wyzwań przyszłości, wskazano na te, które mogą mieć perspektywicznie największy wpływ na kształtowanie obiektów dla dzieci: większa aktywność osób niepełnosprawnych, nasilające się problemy zdrowotne i psychologiczne dzieci, intensyfikacja zmian środowiskowych i klimatycznych. Architektura przyszłości powinna odpowiadać na już zdefiniowane wyzwania, a także reagować na pojawiające się nowe.

Słowa kluczowe: architektura przeznaczona dla dzieci, środowisko, przyszłość, edukacja 